\title{
A framework to assess national level vulnerability from the perspective of food security: The case of coral reef fisheries
}

\author{
Sara Hughes ${ }^{a, 1, *}$, Annie Yau ${ }^{a, 2}$, Lisa Max ${ }^{b}$, Nada Petrovic ${ }^{c, 3}$, Frank Davenport ${ }^{d}$, \\ Michael Marshall $^{d, 4}$, Timothy R. McClanahan ${ }^{e}$, Edward H. Allison ${ }^{f, 5}$, Joshua E. Cinner ${ }^{g}$ \\ a Bren School of Environmental Science and Management, University of California, Santa Barbara, CA 93106, USA \\ ${ }^{\mathrm{b}}$ Department of Ecology, Evolution and Marine Biology, University of California, Santa Barbara, CA 93106, USA \\ ${ }^{\mathrm{c}}$ Department of Physics, University of California, Santa Barbara, CA 93106, USA \\ d Department of Geography, University of California, Santa Barbara, CA 93106, USA \\ e Wildlife Conservation Society, Marine Programs, Bronx, NY 10460, USA \\ ${ }^{\mathrm{f}}$ WorldFish Center, P.O. Box 500, GPO, 10670 Penang, Malaysia \\ ${ }^{\mathrm{g}}$ ARC Centre of Excellence for Coral Reef Studies, James Cook University, Townsuille, QLD 4811, Australia
}

\section{A R T I C L E I N F O}

Published on line 21 August 2012

Keywords:

Adaptive capacity

Exposure

Resilience

Sensitivity

Developing countries

Social-ecological systems

Climate change

\begin{abstract}
A B S T R A C T
Measuring the vulnerability of human populations to environmental change is increasingly being used to develop appropriate adaptation policies and management plans for different economic sectors. We developed a national-level vulnerability index that is specific to food security policies by measuring nations' relative vulnerabilities to a decline in their coral reef fisheries. Coral reef fisheries are expected to decline with climate and anthropogenic disturbances, which may have significant consequences for food security. The vulnerability measure was composed of exposure, sensitivity, and adaptive capacity indicators specific to fisheries, reef management, and food security. The vulnerability index was used to evaluate 27 countries, as data required to fully populate the theoretical framework was limited. Of these, Indonesia and Liberia were identified as most and Malaysia and Sri Lanka as least vulnerable nations. Our analysis revealed two common national vulnerability characterizations: low income countries with low adaptive capacity and middle-income countries with higher adaptive capacity but high sensitivity. These results suggest developing contextspecific policies and actions to build adaptive capacity in the low-income countries, and to decrease sensitivity in middle-income countries. Comparing our food security evaluation to a more general vulnerability approach shows that they produce different priority countries and associated policies.
\end{abstract}

Published by Elsevier Ltd.

\footnotetext{
* Corresponding author. Tel.: +1 810835 1748/303 497 2872; fax: +1 3034978401.

E-mail address: shughes@ucar.edu (S. Hughes).

1 Present address: National Center for Atmospheric Research, FL2 3106D, Boulder, CO 80307, USA.

2 Present address: Office of the Assistant Administrator, Office of Atmospheric Research, National Oceanic and Atmospheric Administration, Silver Spring, MD 20910, USA.

${ }^{3}$ Present address: Center for Research on Environmental Decisions, 406 Schermerhorn-MC5501, Columbia University, New York, NY 10027, USA.

${ }^{4}$ Present address: United States Geological Survey, Flagstaff, AZ, USA.

${ }^{5}$ Present address: School of International Development, University of East Anglia, Norwich NR4 7TJ, UK. 1462-9011/\$ - see front matter. Published by Elsevier Ltd.
}

http://dx.doi.org/10.1016/j.envsci.2012.07.012 


\section{Introduction}

Enhancing food security is a rising concern and a central aim for development agencies, such as the United States Agency for International Development (USAID) and the United Nations' World Food Programme (WFP). Food security is a concept with multiple definitions and possibilities for interpretation (Dilley and Boudreau, 2001; Gregory et al., 2005). The United Nations Food and Agriculture Organization (FAO) definition of food security: "when all people, at all times, have physical, social, and economic access to sufficient, safe, and nutritious food that meets their dietary needs and food preferences for an active and healthy life" (FAO, 2011) is adopted in this paper. Improved assessments of environmental and food production changes, as well as the capacity of people to adapt, would enable decision makers and governments to proactively design and implement policies and aid strategies. While substantial attention has been focused on the relationship between food security, environmental change and terrestrial agriculture (e.g., Schmidhuber and Tubiello, 2007; Brown and Funk, 2008; Luers et al., 2003), less research has examined how fisheries declines will impact the food security of countries dependent on those fisheries (Smith et al., 2010). This is particularly so for the small island and small coastal states of developing countries, where fisheries associated with coral reefs are especially important (Burke et al., 2011).

Coral reefs are undergoing large-scale ecological change associated with climate change, pollution, and increasing fishing effort (Pandolfi et al., 2011; McClanahan, 2002). Because these fisheries are sources of protein, micronutrients and income, they provide a useful system for evaluating food security and vulnerability to environmental change (Hicks et al., 2009; Whittingham et al., 2003; Cinner et al., 2012). On many poorly-managed coral reefs, the yields, diversity, and catch per unit effort of associated fisheries have been, and are predicted to continue declining due to anthropogenic forces such as land use change, pollution, ocean acidification, rising seawater temperatures, and over-fishing (Smith and Buddemeier, 1992; Wilkinson and Buddemeier, 1994; Newton et al., 2007; Halpern et al., 2008). Consequently, the aim of our study is to develop a framework to identify the most vulnerable regions, the mechanisms creating this vulnerability, and the potential policy interventions that may reduce this food security vulnerability. We calculate vulnerability as the degree to which a country is susceptible to a decline in coral reef fisheries as a food source and its ability to respond to the decline.

The theoretical and empirical literature on vulnerability of coral reef fisheries and their contribution to food production is reviewed and used to derive adaptive capacity, exposure, and sensitivity metrics. Results from our food-security specific framework are compared to those from the more generic Reefs at Risk report (Burke et al., 2011). The specific features of vulnerability and relevant policy considerations are evaluated to consider appropriate methods for constructing vulnerability metrics.

\section{Conceptualizing vulnerability and food security}

\subsection{National scale vulnerability to environmental change}

Vulnerability includes the "exposure and sensitivity of a system to single or multiple stressors" (Smit and Wandel, 2006) and the capacity of that system to successfully adjust to or capitalize on the effects of those stressors. The attention devoted to conceptualizing and measuring human vulnerability to environmental change has increased as human population growth and climate change issues become increasingly relevant and acute (Adger, 2006; Adger and Kelly, 1999; Handmer et al., 1999). Research has attempted to generate either a universal framework for assessing vulnerability or to measure vulnerability specific to particular types of change, such that context-specific policies and management can be developed (McClanahan et al., 2008, 2009). These efforts have improved understanding of the contextual drivers and dynamics of vulnerability and highlighted weaknesses and potential tradeoffs between generic and highly specific vulnerability indices.

Vulnerability assessments can be broad or specific. Broad vulnerability assessments focus on multiple sectors or globally defined policy areas but the implications for policy interventions are often not focused enough to determine implementation needs. Specific vulnerability assessments target identified problems in order to recommend the specific intervention and scale of policies needed to reduce vulnerability (Leurs, 2005; Ionescu et al., 2009). For example, broad assessments of threats to coral reefs, such as the World Resource Institute's Reefs at Risk project (Burke et al., 2011), can lack the specific recommendations needed by policy makers or governments to understand and manage environmental change as it relates to immediate socio-economic problems, such as food security.

The components of vulnerability to a given hazard exposure, sensitivity and adaptive capacity - vary across space and time, regardless of the spatio-temporal scale of the stressor (Turner et al., 2003). As a result, most vulnerability analyses tend to be specific to a place and context while linked across scales (Turner et al., 2003), and are most frequently assessed and influential at national and global levels (Pelling and Uitto, 2001; Brooks et al., 2005; Allison et al., 2009). Globalization, trade and linked economies result in responses and adaptive pathways to coastal environmental stressors that exhibit high levels of connectivity and lend themselves to analyses at the regional or national scales (Adger, 2006). The costs of national level analyses can be large due to the scarcity of comprehensive and high quality national data and the difficulties of integrating the variability in vulnerability across these large systems. However, the benefit of assessing vulnerability at the national level is that the results can influence national-level policy responses and adaptive management strategies. Allison et al. (2009) and Burke et al. (2011), for example, conducted national-level assessments relevant to coastal vulnerability. However, these studies did not address sector-specific policy needs, which is a frequent deficiency in the vulnerability literature. Bell et al. (2011) 
examined national level vulnerability in terms of food security for Pacific Island countries and territories, but included all fisheries and aquaculture and only examined vulnerability in the face of one major driver (climate change). The aim of this paper, therefore, is to develop a more specific framework and methodology and provide an analysis of national level vulnerability from a food security perspective, where coral reef fisheries provide a useful case study.

\subsection{Coral reefs, food security and environmental change}

Coral reefs are tropical nearshore marine ecosystems that are home to a high diversity of fish, invertebrates, algae, and reef-building corals. Coral reef fisheries are defined here as fisheries that harvest organisms associated with coral reefs and exclude pelagic and other non-reef species even if they are harvested nearshore. Coral reef fisheries are often artisanal and subsistent and use low capital and low technology to harvest both fish and invertebrates, primarily for local consumption and secondarily for trade (Cinner and McClanahan, 2006). While coral reefs are globally valued for their high biodiversity, locally they are a productive and easily accessible food resource for millions of people (Kawarazuka and Bene, 2011). In Southeast Asia, for example, coral reef fisheries generate US $\$ 2.4$ billion (Burke et al., 2002) while in the Caribbean they generate US\$ 310 million per year by providing a range of ecosystem services to the economy and society (Burke and Maidens, 2004). As part of national food systems around the world, coral reef fisheries contribute to the food security of those countries. According to Dulvy and Allison (2009), "catches by subsistence and artisanal fisheries make up more than half of the essential protein and mineral intake for over 400 million people in the poorest countries in Africa and south Asia." For example, almost $60 \%$ of the animal protein of an average Indonesian resident comes from fish (Dey et al., 2005) and in eight Pacific Island countries and territories, 50-90\% of animal protein in the diet of rural communities comes from fish (Bell et al., 2009).

Developing countries' reliance on and use of subsistence coral reef fisheries for food and income is complicated by access arrangements and export issues. Subsistence fishers' access to food and income can be limited by highly profitable, large-scale fisheries with sufficient capital to compete globally (Kent, 1997; Pauly et al., 2005; Atta-Mills et al., 2004). Declining yields and increasingly restricted access may have serious implications for food security in some parts of the world. Policy and management efforts to address this issue will be assisted by evaluating the national context as it relates to food security.

\section{Methods: measuring national level vulnerability to coral reef fisheries decline}

This paper scales national vulnerability to declining coral reef resources to understand the causes of vulnerability. We used data from a range of sources to quantify vulnerability as a function of three components: a country's exposure to environmental change and disturbances, its sensitivity to this change, and its adaptive capacity, or potential to respond to the change (Adger, 2006).

\subsection{Exposure}

We define exposure as the degree to which a country's coral reef fisheries are subject to degradation due to anthropogenic threats. Exposure was estimated using scores of cumulative impact that quantify the threat to the world's coral reefs from a set of 38 categories. These categories encompass anthropogenic drivers of change in marine ecosystems and include fishing, land use changes, invasive species, shipping, and pollution (see Halpern et al. (2008) for detailed methods on quantifying cumulative impact). Using a map of coral reefs within each country's exclusive economic zone (EEZ) produced by the World Conservation Monitoring Centre, we calculated the cumulative impact scores for each $1-\mathrm{km}^{2}$ grid of a country's coral reefs. These cumulative impact scores for each grid were then averaged for a country's coral reefs. A higher cumulative impact score indicates a country whose reefs are subject to greater exposure to anthropogenic threats.

\subsection{Sensitivity}

Sensitivity was defined as the degree to which a country is dependent on coral reef fisheries for food. Our method for quantifying sensitivity draws on a study by Luers et al. (2003) that incorporates both the dependence on a food resource and the proximity of the food system to some damage threshold. Therefore, a country would be considered highly sensitive to a change in coral reef fisheries if it is highly dependent on reef fisheries for protein and also has inadequate protein sources. We use the formula:

$S=\left\{\frac{\text { Reef fisheries dependence }}{\text { Protein intake relative to threshold }}\right\}$

$=f\left(\frac{|\mathrm{dW} / \mathrm{d} x|}{\left(\mathrm{W} / \mathrm{W}_{0}\right)}\right)$

$=\frac{\text { Coral reef protein } / \text { Total protein }}{\text { Total protein/Protein threshold }}$

where $\mathrm{W}$ is the well-being of the system indicated by the total amount of daily protein a person consumes in grams, $x$ is a stressor or the decrease in the amount of coral reef protein harvested (caused by the degradation of the reef), and $W_{0}$ is a threshold value of well-being below which the person is not receiving enough daily protein. In this paper, we use the FAO and WHO recommended minimum amount of daily protein needed to maintain health (30 g protein per day) as our measure for $W_{0}$. The change in $W$ with respect to $x,|d W / d x|$, quantifies how much well-being, $W$, changes due to a perturbation in the stressor. The ratio $\mathrm{W} / \mathrm{W}_{0}$ quantifies the nearness of the system to the threshold value-as this ratio declines the system nears the threshold and the sensitivity increases.

We assumed a positive, linear relationship between coral reef protein harvested and protein consumption, such that $|\mathrm{dW} / \mathrm{d} x|$ scales as the fraction of coral reef protein out of total protein. We made this assumption because the functional form of $|d W / d x|$ is impossible to estimate with existing data: it would require a mathematical relationship between the 
decrease in amount of coral reef protein harvested and protein consumption. However, this term still captures the core idea that a country is more sensitive to reef degradation if a higher percentage of its total protein is derived from reef fisheries.

Total protein consumption data from the FAOstat dataset between 1995 and 2005 were used to calculate the sensitivity of countries to declines in coral reef fisheries. Coral reef protein was distinguished from total fish protein by excluding protein from fish oil, pelagic fish, and two miscellaneous categories of fish. Demersal fish, crustaceans, mollusks and cephalopods are common to measures of total and reef protein. A higher sensitivity value indicates a country is highly dependent on coral reef protein as a protein source, and its protein consumption is close to or below the minimum recommended protein consumption level. Recent research (e.g., Kawarazuka and Bene, 2010) highlights that the main direct nutritional contribution of seafood to diets in all but the most fishdependent populations is through provision of micro-nutrients (essential fatty acids, minerals, vitamins). However, data on supply and demand for these is seldom available, and protein consumption presents a reasonable proxy for nutrient-dense foods.

\subsection{Adaptive capacity}

Adaptive capacity was defined as a country's potential to respond to changes in the contribution of reef fisheries to the food system and ability to take advantage of or mitigate these changes. We disaggregated adaptive capacity into four categories: assets, flexibility, learning, and social organization (Cinner et al., 2009).

\subsubsection{Assets}

Assets were defined as the resources a country has at its disposal to assist the fisheries sector in responding to a decline in reef fisheries. Assets are components of adaptive capacity because they represent the ability of a country to leverage resources in response to changes in the food system. We measured assets as physical (man-made), financial and natural. A country that is adapting well would have adequate levels of all three types of assets in order to leverage resources to adjust to change.

The percentage of a country's population with access to sanitation as reported by the World Bank in 2000 was used as a measure of a country's physical assets. This metric has been shown to be a key indicator of vulnerability (Brooks et al., 2005) as it represents the extent of man-made infrastructure that a country's residents have at their disposal and is a better proxy than, for example, density of road networks, which does not correlate as well with the development status of a country as it is dependent on physical geography. As an indicator of a country's financial assets, we used average GDP per capita from 1995 to 2005 as reported by the World Bank. As an indicator of natural assets we used reef area per capita in each country's EEZ. We assumed that countries with a higher percentage of the population with access to sanitation, higher per-capita GDP, and a higher reef area per capita will have a greater ability to cope with changes in coral reef fisheries via compensatory mechanisms, alternative economic activities, or new fishing methods.

\subsubsection{Flexibility}

Flexibility refers to the range of options a country has to meet nutritional and livelihood needs if existing resource availability declines. Flexibility is a component of adaptive capacity because it represents the ability of a country to adjust through substitution of goods, such as alternate protein sources, production technologies, and accessibility of food resources. A country with more flexibility in production, trade and livelihoods is expected to adapt better than countries with low flexibility.

Flexibility was estimated directly as a country's trade balance as reported by the World Bank and OECD national accounts data, standardized by its average GDP between 1995 and 2005. A greater trade balance indicates greater flexibility to invest in food imports if domestic production is insufficient or to adapt to a reduction in exports resulting from a decline in the production of reef fisheries marketed internationally.

The GINI index, a measure of income inequality, was also used as an additional, indirect measure of a country's flexibility. We assumed that countries with high inequality exhibit a greater difficulty in shifting resources to support the more vulnerable populations at the lower end of the income distribution. Conversely, we assumed that countries with lower GINI coefficients exhibit a social-political context in which economic opportunities and burdens are shared more equally and more people would have access to alternative food sources in the face of coral reef fisheries decline.

\subsubsection{Learning}

Learning was defined as a country's organizational and institutional capacity to access and act on information. Learning is a component of adaptive capacity because it allows a country to recognize and respond appropriately to environmental changes that affect its food systems. A country that is adapting well would be able to acquire, synthesize, and incorporate new knowledge into decision making, including knowledge from resource users. Therefore, two of the most critical components of learning are the use of science in fisheries management and the education level of the population.

The degree to which countries use science in decision making for fisheries was derived from the survey dataset collected from representative national officials by Mora et al. (2009) between 2007 and 2009. Officials were asked to report on the education level of fisheries managers, the use of holistic fisheries models, environmental and biological data, the frequency of assessments, and the extent to which precautionary measures were used in decision making. A higher score on this scientific robustness scale indicates a greater capacity for learning.

We also measured learning as the average adult literacy rate (15 years and older) in a country between 1995 and 2005 as reported by the World Bank. Declines in literacy rates may occur in poor countries when governments reduce spending on education and health. We assume that countries with higher adult literacy rates have more resources dedicated to education; their populations will be better equipped to respond to changes to food systems, access alternative food sources, and incorporate new knowledge that will improve their adaptive capacity. 


\subsubsection{Social organization}

Social organization was defined as the degree to which a country's institutional and policy frameworks support or hinder food security. Social organization is a component of adaptive capacity because it indicates the ability of a country to effectively take steps toward change and implement policies and programs that will lead to successful adaptation. We estimated social organization using both a national measure of overall governance and two specific fisheries-related measures.

The Government Effectiveness Index, developed by the World Bank, was used as a metric for overall governance. It was derived based on third party surveys of businesses, households, and NGOs. Using these index values allows us to gain a relative understanding of government effectiveness in our target countries (Brewer et al., 2007).

For fisheries-related measures we used the quality of fisheries management and incorporation of fisheries in planning documents in a country. The quality of fisheries management was estimated using the average scores from the surveys conducted by Mora et al. (2009) for a country's policy transparency, implementation, use of subsidies, and presence of foreign fishing; the assumption was that countries with higher quality fisheries management will be more able to adapt their management systems to change in resource productivity.

Government effectiveness as it pertains to fisheries management and policy was also examined by assessing whether governments have been responding to identified external threats to reefs and fisheries. Specifically, we used a content analysis method to evaluate the degree to which fisheries are incorporated into national-level planning processes for development and climate change adaptation, based on a methodology developed by Thorpe et al. (2006) and Ekbom and Bojö (1997). We began by selecting a national-level government planning document from each country that was one of the following in order of preference: a climaterelated adaptation plan, a national development plan, or other related plan such as a disaster preparedness and response plan. We then analyzed the documents according to four diagnostic categories: (1) the mention of fisheries-related issues, (2) the acknowledgement of the causal linkages between fisheries-related issues and poverty-related issues,
(3) the specification of fisheries-related responses and actions, and (4) the linkage between the document formulation process and fisheries related policy and planning processes. For each diagnostic, a score between 0 and 3 was given: 0 = no mention, 1 = mentioned, but not elaborated upon, 2 = elaborated, 3 = best practice. Scores for each of the four diagnostic categories were summed in order to provide a score out of 12 possible points. Countries with a high value of government effectiveness and a high score for fisheries policy are expected to have greater social organization pertaining to fisheries management, to develop better responses to coral reef fisheries declines, and to have greater success in implementing measures to prevent and/or mitigate these declines (Table 1).

\subsection{Country selection}

Our aim was to generate a list of countries with coral reef fisheries and available data for each of our vulnerability indicator components. In our first round of evaluations, we selected all countries that had coral coverage based on the UNEP World Conservation Monitoring Centre for a total of 86 countries. This list was reduced to 27 countries based on the availability of the above adaptive capacity indicator data for the years between 1995 and 2005. This process allowed us to evaluate the vulnerability of countries in a theoretically rigorous way but tended to favor large and organized countries that collate and submit these data.

\subsection{Calculating vulnerability}

The index values were standardized based on maximum values in our dataset and placed on a scale of zero to one using the following conversion: $\left(X-X_{\min }\right) /\left(X_{\max }-X_{\min }\right)$. In this way, the maximum value within each index was set to a relative value of one. Vulnerability was calculated as (Exposure + Sensitivity) - Adaptive Capacity (Fig. 1), so that lower scores indicate lower levels of vulnerability. The vulnerability scores were in turn standardized so that zero is the lowest possible vulnerability score and three is the highest possible vulnerability score. By standardizing within our analyses, these calculated values were relative and only meaningful

\section{Table 1 - Summary of adaptive capacity indicators used in this study.}

\begin{tabular}{|c|c|c|c|}
\hline Category & Indicator & Measures & Data Source \\
\hline Assets & $\begin{array}{l}\text { Percentage of population with } \\
\text { access to sanitation }\end{array}$ & Physical infrastructure & World Bank \\
\hline Assets & GDP per capita & Financial assets & IMF World Economic Outlook Database \\
\hline Assets & Reef area per capita & Natural assets & UNEP Coral Reef Atlas \\
\hline Flexibility & $\begin{array}{l}\text { Trade balance standardized } \\
\text { by GDP per capita }\end{array}$ & $\begin{array}{l}\text { Ability to invest } \\
\text { in food imports }\end{array}$ & World Bank and OECD national accounts \\
\hline Flexibility & GINI index & Income inequality & World Bank \\
\hline Learning & Scientific robustness & $\begin{array}{l}\text { Use of scientific information } \\
\text { in fisheries policy }\end{array}$ & Mora et al. (2009) \\
\hline Learning & Adult literacy rate & General education level & World Bank \\
\hline Social Organization & $\begin{array}{l}\text { Policy transparency, implementation, } \\
\text { use of subsidies, foreign fishing }\end{array}$ & $\begin{array}{l}\text { Overall quality of fisheries } \\
\text { management }\end{array}$ & Mora et al. (2009) \\
\hline Social Organization & Government effectiveness index & Overall quality of governance & World Bank \\
\hline Social Organization & $\begin{array}{l}\text { Score indicating mention of fisheries } \\
\text { management in national-level } \\
\text { policy documents }\end{array}$ & $\begin{array}{l}\text { Government effectiveness in } \\
\text { fisheries management }\end{array}$ & $\begin{array}{l}\text { Content analysis of policy documents } \\
\text { (Thorpe et al., 2006; Ekbom and Bojö, 1997) }\end{array}$ \\
\hline
\end{tabular}




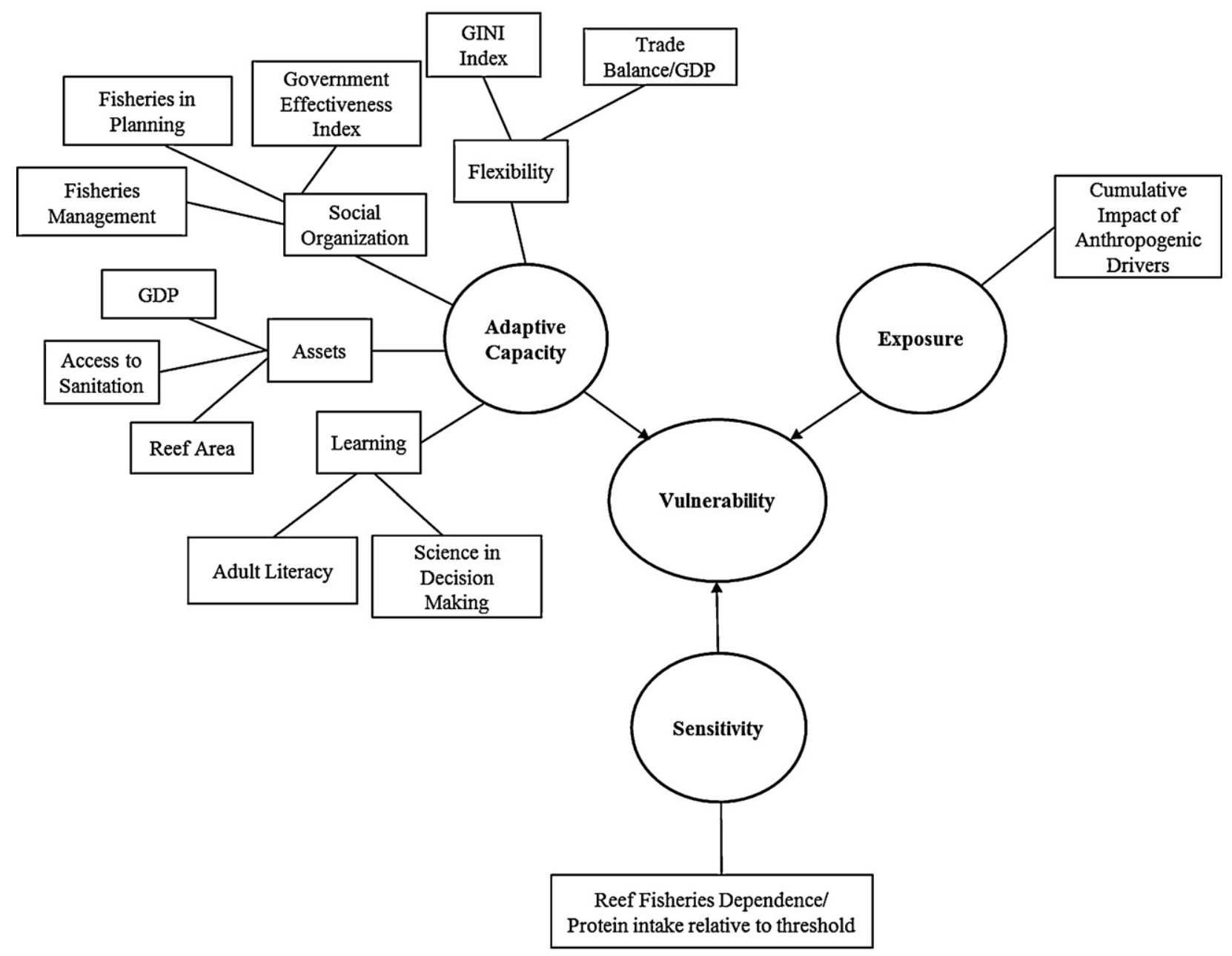

Fig. 1 - Structure of the fisheries and food security-specific vulnerability index, composite sub-indices, and components indicators.

as they relate to this set of countries and data. The mean value for all countries will be equal to zero and countries with larger positive values will have the highest relative vulnerability. We calculated the percent of vulnerability explained by each variable (exposure, sensitivity, adaptive capacity) using Principal Component Analysis (PCA) (e.g., Jolliffe, 1986).

We chose to treat each component and the various metrics used to measure each component equally. We did not use any weighting system. This choice was deliberate on the part of the authors as weights reflect a value system specific to a given policy context. Our goal in this paper is not to guide country specific polices but rather to demonstrate the creation and application of a vulnerability index. Policy makers and other researchers who wish to apply the index of course may wish to weight the various components or indicators based on the specific priorities of the decision being made (e.g., McClanahan et al., 2008). Those who do decide to employ weights should consult the Multi-Objective Decision Analysis literature for guidance on soliciting and incorporating weighted criteria into the decision process (Hammond et al., 1999; Saaty, 1986). ${ }^{6}$

${ }^{6}$ We thank an anonymous reviewer for highlighting this for us.

\subsection{Comparing approaches}

To assess the relative gains of applying a food security perspective to national-scale vulnerability assessments, our results were compared to those from the World Resource Institute's most recent Reefs at Risk report, which assessed the general vulnerability of countries with coral reefs to the threat of reef loss due to coastal development, watershed-based pollution, marine-based pollution, overfishing, thermal stress and ocean acidification using a wide range of data sources and methods (Burke et al., 2011). The resulting threat levels for the reefs in each country were ultimately categorized as low, medium, or high, with those reefs classified as medium or high considered "threatened." Measures of adaptive capacity and dependence on reefs are then included in a vulnerability assessment of the social and economic implications of reef loss. Reef dependence is measured as the proportion of the population that lives near reefs or fish reefs, the country's reef-associated exports, nutritional dependence on fish, reefassociated tourism, and shoreline protection. Adaptive capacity is measured as economic resources, education, health, governance (including fisheries subsidies), access to markets, and agricultural resources. 


\section{Results}

Country-specific vulnerability scores ranged from 0 to 2.33 (Table 2). Single variable regression analyses indicated that adaptive capacity had a greater influence on vulnerability compared to exposure and sensitivity. PCA revealed that exposure, sensitivity, and adaptive capacity explained $39 \%$, $34 \%$ and $27 \%$ of the variation in vulnerability scores, respectively. The exposure values were driven largely by Indonesia and the Philippines, which had very high exposure scores (1.00 and 0.88 , respectively) compared to all the other countries, which had exposure scores below 0.20 .

The component scores for each country indicated that there was no single driver of vulnerability or a single underlying mechanism that makes a country particularly vulnerable to declines in coral reef fisheries; rather, countries experienced vulnerability as the result of a unique combination of adaptive capacity, sensitivity and exposure (Fig. 2). In this way we identified countries whose particular combination of factors warranted greater attention or provided an interesting combination of factors for further evaluation. For example, Indonesia and Liberia were the most vulnerable countries overall, but the drivers of their high levels of vulnerability were different: Indonesia had the highest exposure levels while Liberia's vulnerability resulted from very high sensitivity to coral reef fisheries decline and the lowest level of adaptive capacity. Liberia's sensitivity score was driven by its close proximity to the $30 \mathrm{~g} /$ capita/day threshold recommended by the FAO and WHO; Liberia's average daily protein intake was $34.5 \mathrm{~g}$, the lowest of any of our studied countries. Unlike Liberia, other countries with the lowest vulnerability scores, such as Sri Lanka, Malaysia, and the Dominican Republic, had high adaptive capacity scores relative to their levels of exposure and sensitivity.

A number of African countries, including Kenya, Cameroon, Ivory Coast, and Comoros, had higher than average vulnerability scores despite relatively small coral reef areas. These countries had very low adaptive capacity scores and higher than average levels of sensitivity to declines in coral reef fisheries production. Another category of vulnerability was found in Latin American countries such as Brazil, Costa Rica, and Mexico, which had high adaptive capacity but very high sensitivity, which resulted in slightly below-average vulnerability scores.

As described above, adaptive capacity played the largest role in determining vulnerability scores. Further analysis of the indicators used in the adaptive capacity scores reveals patterns among the countries (Table 3). First, there is not much variation in the social organization scores, which ranged from 0.75 to 1.99 out of a total possible score of 3. Flexibility scores were consistently low for the 27 countries (with possible scores ranging from -1 to 1 ), and often less than zero due to the consistently poor GINI scores. The differences in adaptive capacity, therefore, are driven largely by differences in assets and learning. For example, the country with the lowest

Table 2 - Standardized exposure, sensitivity, adaptive capacity, and vulnerability scores where vulnerability = (exposure + sensitivity) - adaptive capacity. ${ }^{\mathrm{a}}$

\begin{tabular}{|c|c|c|c|c|}
\hline Country & Exposure & Sensitivity & Adaptive capacity & Vulnerability \\
\hline Indonesia & 1.00 & 0.98 & 0.37 & 2.33 \\
\hline Liberia & 0.0050 & 0.92 & 0.00 & 1.65 \\
\hline Ivory Coast & 0.00025 & 0.91 & 0.15 & 1.48 \\
\hline Kenya & 0.016 & 0.81 & 0.10 & 1.45 \\
\hline Philippines & 0.88 & 0.40 & 0.57 & 1.43 \\
\hline Honduras & 0.019 & 0.90 & 0.23 & 1.41 \\
\hline Cameroon & 0.00044 & 0.91 & 0.25 & 1.37 \\
\hline Egypt & 0.10 & 0.87 & 0.45 & 1.24 \\
\hline Cambodia & 0.00051 & 0.90 & 0.43 & 1.19 \\
\hline Tanzania & 0.076 & 0.94 & 0.55 & 1.19 \\
\hline Bangladesh & 0.00 & 0.88 & 0.46 & 1.14 \\
\hline Comoros & 0.0067 & 0.74 & 0.34 & 1.12 \\
\hline Nicaragua & 0.012 & 0.89 & 0.51 & 1.12 \\
\hline Cape Verde & 0.0065 & 0.86 & 0.50 & 1.08 \\
\hline India & 0.084 & 0.44 & 0.31 & 0.94 \\
\hline Senegal & 0.0015 & 0.66 & 0.47 & 0.92 \\
\hline Madagascar & 0.037 & 0.21 & 0.063 & 0.91 \\
\hline China & 0.025 & 0.78 & 0.65 & 0.87 \\
\hline Brazil & 0.019 & 0.91 & 0.78 & 0.86 \\
\hline Costa Rica & 0.014 & 1.00 & 0.89 & 0.85 \\
\hline Panama & 0.025 & 0.78 & 0.71 & 0.82 \\
\hline Mexico & 0.038 & 0.88 & 0.88 & 0.75 \\
\hline Trinidad and Tobago & 0.0015 & 0.93 & 0.91 & 0.74 \\
\hline Thailand & 0.053 & 0.85 & 1.00 & 0.62 \\
\hline Dominican Republic & 0.016 & 0.39 & 0.68 & 0.45 \\
\hline Sri Lanka & 0.019 & 0.12 & 0.84 & 0.023 \\
\hline Malaysia & 0.083 & 0.00 & 0.80 & 0.00 \\
\hline Mean & 0.094 & 0.74 & 0.51 & 1.04 \\
\hline
\end{tabular}

${ }^{a}$ Values for each variable have been standardized individually. 


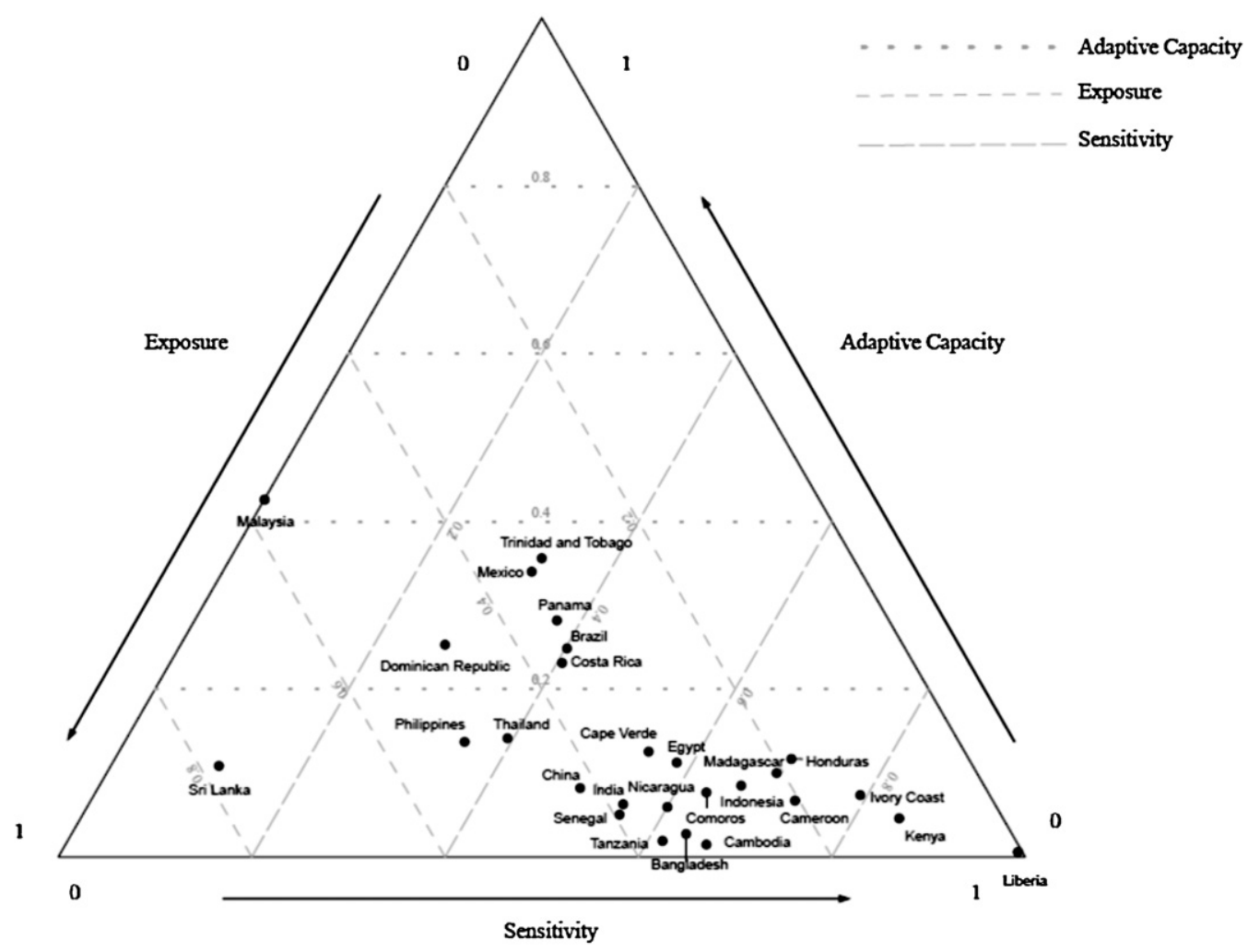

Fig. 2 - Ternary plot showing the unique combination of factors underlying individual countries' vulnerability scores.

Table 3 - Scores for the components of adaptive capacity: assets, flexibility, learning and social organization.

\begin{tabular}{|c|c|c|c|c|c|}
\hline Country & Assets & Flexibility & Learning & Social organization & Adaptive capacity total \\
\hline Liberia & 0.058 & -0.36 & 0.44 & 1.20 & 1.34 \\
\hline Madagascar & 0.42 & 0.11 & 0.28 & 0.75 & 1.57 \\
\hline Kenya & 0.31 & 0.041 & 0.50 & 0.84 & 1.70 \\
\hline Ivory Coast & 0.23 & 0.54 & 0.22 & 0.89 & 1.89 \\
\hline Honduras & 1.01 & -0.25 & 0.50 & 0.93 & 2.19 \\
\hline Cameroon & 0.52 & 0.28 & 0.31 & 1.15 & 2.27 \\
\hline India & 0.23 & 0.47 & 0.16 & 1.60 & 2.46 \\
\hline Comoros & 1.26 & -0.70 & 0.70 & 1.34 & 2.60 \\
\hline Indonesia & 0.78 & 0.55 & 0.19 & 1.16 & 2.68 \\
\hline Cambodia & 0.11 & 0.13 & 1.24 & 1.42 & 2.90 \\
\hline Egypt & 1.19 & 0.54 & 0.16 & 1.08 & 2.97 \\
\hline Bangladesh & 0.45 & 0.59 & 0.00 & 1.99 & 3.03 \\
\hline Senegal & 0.47 & 0.11 & 1.41 & 1.07 & 3.06 \\
\hline Cape Verde & 0.68 & -0.60 & 1.40 & 1.71 & 3.18 \\
\hline Nicaragua & 0.81 & -0.48 & 1.83 & 1.05 & 3.20 \\
\hline Tanzania & 0.34 & 0.38 & 1.24 & 1.39 & 3.34 \\
\hline Philippines & 1.26 & 0.18 & 0.31 & 1.66 & 3.41 \\
\hline China & 0.59 & 0.42 & 1.25 & 1.48 & 3.74 \\
\hline Dom. Rep. & 1.29 & 0.0053 & 1.00 & 1.53 & 3.83 \\
\hline Panama & 1.79 & 0.028 & 0.57 & 1.54 & 3.93 \\
\hline Brazil & 1.33 & -0.12 & 1.89 & 1.09 & 4.20 \\
\hline Malaysia & 1.78 & 0.53 & 0.34 & 1.63 & 4.28 \\
\hline Sri Lanka & 0.97 & 0.35 & 1.14 & 1.94 & 4.40 \\
\hline Mexico & 1.70 & 0.11 & 1.60 & 1.17 & 4.58 \\
\hline Costa Rica & 1.59 & 0.15 & 1.58 & 1.27 & 4.59 \\
\hline Trin. \& Tob. & 2.02 & 0.60 & 0.25 & 1.80 & 4.67 \\
\hline Thailand & 1.29 & 0.40 & 1.34 & 1.97 & 5.00 \\
\hline
\end{tabular}

adaptive capacity score, Liberia, has a score of 0.058 (out of 3) for assets and 0.44 (out of 2) for learning while the country with the highest adaptive capacity score, Thailand, has scores of 1.29 and 1.34 , respectively.

\subsection{Comparing approaches}

The food security-oriented and the more general Reefs at Risk vulnerability assessments produced some similarities and 


\begin{tabular}{|c|c|c|}
\hline Country & $\begin{array}{l}\text { Vulnerability: } \\
\text { food security } \\
\text { approach }\end{array}$ & $\begin{array}{c}\text { Vulnerability: } \\
\text { general approach } \\
\text { (Burke et al., 2011) }\end{array}$ \\
\hline Indonesia & 2.33 & Very High \\
\hline Liberia & 1.65 & - \\
\hline Ivory Coast & 1.48 & - \\
\hline Kenya & 1.45 & High \\
\hline Philippines & 1.43 & Very High \\
\hline Honduras & 1.41 & Medium \\
\hline Cameroon & 1.37 & - \\
\hline Egypt & 1.24 & Medium \\
\hline Cambodia & 1.19 & Medium \\
\hline Tanzania & 1.19 & Very High \\
\hline Bangladesh & 1.14 & Low \\
\hline Comoros & 1.12 & Very High \\
\hline Nicaragua & 1.12 & Low \\
\hline Cape Verde & 1.08 & - \\
\hline India & 0.94 & Medium \\
\hline Senegal & 0.92 & - \\
\hline Madagascar & 0.91 & Very High \\
\hline China & 0.87 & Medium \\
\hline Brazil & 0.86 & Low \\
\hline Costa Rica & 0.85 & Medium \\
\hline Panama & 0.82 & High \\
\hline Mexico & 0.75 & Low \\
\hline Trinidad and Tobago & 0.74 & Medium \\
\hline Thailand & 0.62 & High \\
\hline Dominican Republic & 0.45 & Very High \\
\hline Sri Lanka & 0.023 & High \\
\hline Malaysia & 0.00 & Medium \\
\hline
\end{tabular}

differences in the scaling of national vulnerability (Table 4). There was agreement between the two methodologies that Indonesia, Kenya and the Philippines were very vulnerable countries. However, this was where the agreement ended. Those countries that were the least vulnerable from a food security perspective (i.e., Sri Lanka, Dominican Republic, and Thailand) were considered to be highly vulnerable using the more general assessment. In addition, countries that had near average vulnerability scores using the food security specific metrics had general vulnerability scores that ranged from low to very high (i.e., Nicaragua and Madagascar). In summary, the most vulnerable countries from a food security perspective are also highly vulnerable using a more general vulnerability assessment, but the two methodologies identify different sets of countries as having low and medium range levels of vulnerability.

\section{Discussion}

The aim of our study was to develop a sector scale-specific, policy relevant vulnerability assessment framework focused on food insecurity implications of disturbances to coral reef ecosystems and their associated fisheries. We drew on a range of data sources and theoretical underpinnings to create a vulnerability index based on adaptive capacity, exposure, and sensitivity. We found a considerable range of adaptive capacity, exposure, and sensitivity among the countries studied and, therefore, differences in the overall food security vulnerability to a decline in reef fisheries. From a food security perspective, and of the countries we examined, the most vulnerable countries to coral reef fisheries decline are Indonesia and Liberia while the least vulnerable countries are Sri Lanka, Malaysia, and the Dominican Republic. Each country in our analysis has a unique suite of factors underlying its vulnerability scores, particularly those countries at the higher end of the vulnerability spectrum.

Adaptive capacity had the greatest effect on vulnerability scores, explaining $39 \%$ of their variation. This suggests there is considerable opportunity to influence vulnerability through interventions that build adaptive capacity. Flexibility mechanisms are lacking in the majority of countries due to high levels of income inequality and exposure of national economies to trade deficits. These aspects of tropical country economies may create challenges in their ability to adapt to the expected increases of climate change impacts and areas of policy needing immediate examination and possible reforms. Further, boosting the country's critical assets - financial, physical, and natural - and the learning capabilities of the population and government is expected to greatly assist the adaptation potential of countries with low adaptive capacity.

In many African countries, such as Kenya, Cameroon, Ivory Coast, and Comoros, low adaptive capacity explains higher than average vulnerability. In these countries, policy and development efforts to promote food security may benefit most from a primary focus on developing assets and flexibility. Actions may include increasing the amount of a country's reefs that is included in marine protected areas, developing other fisheries restrictions to help rebuild fish stocks, increasing alternate protein sources through agriculture and aquaculture, reducing income inequality through pro-poor and fair labor policies and practices, and boosting fair trade and green markets.

Some countries, such as Liberia and Honduras, were classified as vulnerable due to the combination of high levels of food security sensitivity to coral reef fisheries decline and low levels of adaptive capacity. This combination of scores indicates that these countries are likely to be highly sensitive and will struggle to adapt if environmental conditions were to worsen - for example if fish stocks were to decline or ocean acidification to increase - the country's people would be most sensitive and would find it very challenging to adapt. For example, while Liberia has a relatively small reef area, its low levels of protein intake (as reported by the FAO) contribute to its people's vulnerability from a food security perspective. In such cases, policy interventions should focus first on reducing sensitivity and second on increasing adaptive capacity. This specifically means finding ways to increase sources of protein and nutrient-dense foods in these countries and the social mechanisms to make this sustainable.

A third combination of features with policy implications is found in middle income countries such as Thailand, Costa Rica, and Mexico that have high adaptive capacity scores - and thus relatively low vulnerability scores - but high levels of sensitivity. Based on present conditions, their high levels of adaptive capacity are compensating for the sensitivity of their populations to changes in coral reef fisheries productivity. 
However, if conditions in these countries were to deteriorate in any way - if exposure increased due to fishing pressures that exceeds maximum yields or adaptive capacity decreased due to political conflict or natural disasters - their high sensitivity indicates that these changes would have significant consequences; policies to reduce this sensitivity could then be promoted. This would mean leveraging their relatively high levels of adaptive capacity to quickly increase the availability and accessibility of alternative protein sources (McClanahan et al., 2009). If fisheries or ocean conditions were to change slightly, or if political institutions were to erode, the high sensitivity of these countries means their vulnerability could increase greatly. Allison (2011) argues these medium-level developed countries may be among the best locations to develop small to medium size enterprise aquaculture.

In comparing our findings to Burke's et al. (2011) more general approach to evaluating vulnerability to coral reef decline, we find that our food security-specific metrics identify somewhat different priorities for intervention, particularly those for low to medium range generic vulnerability nations. The differences are due to the fisheries-specific indicators for sensitivity and adaptive capacity used in our study that provide information about the implications of coral reef fisheries decline specifically for the country's food system. The general approach would give priority to countries that, from a food security perspective, would not be prioritized highly, and include Thailand, the Dominican Republic, and Sri Lanka. Other countries, such as Honduras and Bangladesh, would be prioritized highly by a food security but not a general approach. In either case, policies and resources may be inefficiently allocated and opportunities to increase food security lost when the evaluations and actions are not sufficiently specific. This comparison found differences between the two approaches that suggest a need for sector and policy-specific diagnostics when developing vulnerability metrics. The major difference between the Reefs at Risk approach and this food security approach is our use of a more specific food security-oriented metric for sensitivity and a more targeted assessment of adaptive capacity as it relates specifically to governing fisheries.

The major limitation of this study - and likely of other efforts to produce national scale, policy-specific vulnerability metrics - is the difficulty in finding the specific data or measuring the key features of vulnerability at the national scale. This is a common problem to overcome when using indicators (Langbein and Knack, 2010; Birkmann, 2007) but the data limitations in this case were particularly severe. Of the 86 countries reporting reef fisheries catch, we were only able to gather sufficient data for 27 even after an extensive search for suitable indicators. The data deficiency was particularly prominent for Small Island Developing States (SIDS), countries that are particularly dependent on coral reefs for food (Thorpe et al., 2005; Bell et al., 2009) and for whom this type of analysis may be particularly valuable. We emphasize that our vulnerability scores are relative and unique to our country list. Some metrics are more readily available, but slightly less theoretically relevant and robust, but could be substituted into our framework (see Appendix A). A challenge to data availability arises from the definition of a nation: islands that are often most dependent on coral reef fisheries are commonly territories of other nations, and data unique to such islands are not available in large databases, such as those maintained by the FAO. However, data from island territories may be available from local government agencies or non-governmental organizations and we encourage investigators and policy makers to find and use metrics that are available for their countries. Improving national data sets on infrastructure, governance, food systems, and fisheries is imperative to further efforts to understand national scale vulnerability.

\section{Conclusions}

The approach to policy-specific, national-scale vulnerability assessment developed in this paper is valuable for conceptualizing key factors influencing national vulnerability, expanding existing frameworks and tools, and prioritizing policy needs and actions associated with food security problems. Future investigations in poor and particularly African countries should examine the factors that best promote adaptive capacity to manage coral reef fisheries and prevent declines in their food production. In middleincome countries the focus should be on factors that best reduce their sensitivities; put simply, such countries have alternatives to eating their coral reef fish populations and efforts to develop them should be a priority. Better data are needed if these types of assessments are to expand geographically, particularly to include vulnerable SIDS countries, and to other factors beyond the fisheries sector. The food security of many countries will be undermined by declining coral reef fisheries resources and using a scale and sector-specific vulnerability should help identify the key constraints and the most useful actions for reducing them.

\section{Acknowledgements}

The authors thank Alice Alldredge, Ben Halpern, Chris Funk, Stuart Sweeney, and James Watson for their input and assistance. The Luce and the John D. and Catherine $\mathrm{T}$. McArthur Foundations provided financial support and the National Center for Ecological Applications and Synthesis provided computing and additional resources.

\section{Appendix A. Revising the framework for SIDS}

Small Island Developing States (SIDS) are of special concern for coral reef fishery management and food security (Thorpe et al., 2005; Ghina, 2003; Bell et al., 2009). Many SIDS have an exceptionally high dependence on the fish and shellfish associated with coral reefs for food. However, due to the lack of available and consistent country-level data, many SIDS were not included in our assessment of food security vulnerability to coral reef fisheries decline. There are 52 countries classified by the United Nations as $\operatorname{SIDS}^{7}$ but only 4

\footnotetext{
${ }^{7}$ A full lists of Small Island Developing states used in this analysis is available from the United Nations at: http://www. un.org/special-rep/ohrlls/sid/list.htm.
} 
of the 27 countries analyzed in this paper are SIDS due to data constraints. This indicates that better data are needed for these countries and, absent such data improvements, an alternative vulnerability index is required to assess the food security vulnerability of the vast majority of SIDS. This appendix is included to determine the components of our vulnerability index that were most data-deficient for SIDS and to propose a scaled-down version that replaces some of the metrics with more readily available but less theoretically robust data alternatives.

Exposure and sensitivity data were available for 35 SIDS. A major impediment to exposure and sensitivity data availability for these countries is the fact that major data collection centers such as the FAO and UNEP do not collect and store data for these countries individually and instead use broader groupings of countries. For example, the FAO does not collect country-level fisheries and nutrition data for Tuvalu, Nauru, or Palau. Exposure data are often collected and analyzed at spatial resolutions that are incompatible with the size of the smallest SIDS. In the case of exposure and sensitivity data, therefore, values could be interpolated from nearby areas or produced through local ground trothing and data collection efforts.

In our analysis, the majority of SIDS were excluded due to a lack of adaptive capacity indicators, in particular the GINI index (available for 19 SIDS) and the adult literacy rate (available for 21 SIDS). Two other adaptive capacity indicators, trade balance standardized by GDP (available for 37 SIDS) and the percentage of the population with access to sanitation (available for 36 SIDS) were somewhat limiting for SIDS, but less problematic. The fisheries-specific measures from Mora et al. (2009) (policy transparency, implementation, use of subsidies, foreign fishing under the social organization category, and scientific robustness under the learning category) tended to have good coverage for SIDS, likely because this was a fisheries specific study. The government effectiveness index component of social organization, developed by the World Bank, was available for 48 SIDS. The coral reef area was obtained from the same source used by Halpern et al. (2008) and is therefore available for all countries that had exposure data. Finally, policy documents used in the analysis following methods of Thorpe et al. (2006) were found for all of the SIDS that had data for the other adaptive capacity indicators and is not likely to be a limiting factor.

As detailed above, the measures that had the worst coverage for SIDS nations were national level measures available from the World Bank (the GINI index and adult literacy). Replacing these two limiting adaptive capacity indicators with cruder proxies would allow for greater SIDS coverage.

To construct a more data rich version of the index, we first replaced the GINI index with life expectancy at birth, which has been argued to be strongly correlated with social inequality as well as total measures of wealth (Riley, 2005). Additionally, this measure is a component of the Human Development Index and was specifically selected to capture notions of human development not captured by GDP, which include inequality (http://hdr.undp.org/en/statistics/hdi/) and was utilized by the Reefs at Risk Revisited report as one of 6 indicators combined to represent adaptive capacity (Burke et al., 2011), and by Bell et al. (2011) as part of their health component of adaptive capacity. Life expectancy at birth is available from the World Bank for 42 SIDS countries, and while it is an indirect measure of inequality may serve as a useful proxy for SIDS.

Secondly, we replaced adult literacy rate with primary education duration in years, which is also available from the World Bank for 44 SIDS countries. This metric was used by Bell et al. (2001) along with literacy to assess their education component of adaptive capacity. Primary education duration is again similar to the measure used by the HDI, which uses a (slightly different) measure of years of schooling as a proxy for education levels. Again, while primary education duration is an indirect measure of literacy, a critical component for learning and flexibility, it may serve as a useful proxy for SIDS.

Table A1 presents a set of variables that includes these changes, and we believe that this new index would provide similar intellectual framework while encompassing significantly more SIDS nations. Given that the final version includes two measures of Learning, Flexibility, and Social Organization, and three measures of Assets, removing percent of population with access to sanitation (the next limiting factor), may provide coverage for a more countries while still maintaining a balanced framework (it has been italicized to indicate this).

Table A1 - A revised vulnerability framework for food security and coral reef fisheries decline that exchanges more readily available but less theoretically robust indicators that would improve coverage of the framework for SIDS.

\begin{tabular}{|c|c|c|c|}
\hline Category & Indicator & Measures & Data Source \\
\hline Assets & Percentage of population with access to sanitation & Physical infrastructure & World Bank \\
\hline Assets & GDP per capita & Financial assets & World Bank \\
\hline Assets & Coral reef area normalized by population & Natural assets & UNEP \\
\hline Flexibility & $\begin{array}{l}\text { Trade balance standardized } \\
\text { by GDP per capita }\end{array}$ & $\begin{array}{l}\text { Ability to invest } \\
\text { in food imports }\end{array}$ & $\begin{array}{l}\text { World Bank and } \\
\text { OECD national accounts }\end{array}$ \\
\hline Flexibility & Life expectancy at birth & Income inequality & World Bank \\
\hline Learning & Scientific robustness & $\begin{array}{l}\text { Use of scientific information } \\
\text { in fisheries policy }\end{array}$ & Mora et al. (2009) \\
\hline Learning & Primary education duration & General education level & World Bank \\
\hline Social Organization & $\begin{array}{l}\text { Policy transparency, implementation, } \\
\text { use of subsidies, foreign fishing }\end{array}$ & $\begin{array}{l}\text { Overall quality of fisheries } \\
\text { management }\end{array}$ & Mora et al. (2009) \\
\hline Social Organization & Government effectiveness index & Overall quality of governance & World Bank \\
\hline
\end{tabular}




\section{R E F E R E N C E S}

Adger, W.N., 2006. Vulnerability. Global Environmental Change 16 (3), 268-281, http://dx.doi.org/10.1016/ j.gloenvcha.2006.02.006.

Adger, W.N., Kelly, P.M., 1999. Social vulnerability to climate change and the architecture of entitlements. Mitigation and Adaptation Strategies for Global Change 4, 253-266.

Allison, E.H. 2011. Aquaculture, Fisheries, Poverty and Food Security. Working Paper. Penang, Malaysia: World Fish Center.

Allison, E.H., Perry, A.L., Badjeck, M.-C., Neil Adger, W., Katrina Brown, Declan Conway, Halls, A.S., et al., 2009. Vulnerability of national economies to the impacts of climate change on fisheries. Fish and Fisheries 10, 173-196, http://dx.doi.org/ 10.1111/j.1467-2979.2008.00310.x.

Atta-Mills, J., Alder, J., Sumalia, R.U., 2004. The decline of a regional fishing nation: the case of Ghana and West Africa. Natural Resources Forum 28 (1), 13-21, http://dx.doi.org/ 10.1111/j.0165-0203.2004.00068.x.

Bell, J.D., Johnson, J.E., Hobday, A.J., 2011. Vulnerability of Tropical Pacific Fisheries and Aquaculture to Climate Change. Secretariat of the Pacific Community, New Caledonia.

Bell, J.D., Kronen, M., Vunisea, A., Nash, W.J., Keeble, G., Demmke, A., Pontifex, S., Andrefouet, S., 2009. Planning the use of fish for food security in the Pacific. Marine Policy 33 (January (1)), 64-76, http://dx.doi.org/10.1016/ j.marpol.2008.04.002.

Birkmann, J., 2007. Risk and vulnerability indicators at different scales: applicability, usefulness and policy implications. Environmental Hazards 7 (1), 20-31, http://dx.doi.org/ 10.1016/j.envhaz.2007.04.002.

Brewer, G.A., Yujin Choi, Walker, R.M., 2007. Accountability, corruption and government effectiveness in Asia: an exploration of World Bank governance indicators. International Public Management Review 8 (2), 200-219.

Brooks, N.W., Neil Adger, P., Mick Kelly, 2005. The determinants of vulnerability and adaptive capacity at the national level and the implications for adaptation. Global Environmental Change Part A 15 (2), 151-163, http://dx.doi.org/10.1016/ j.gloenvcha.2004.12.006.

Brown, M.E., Funk, C.C., 2008. Food security under climate change. Science 319 (February (5863)), 580-581, http:// dx.doi.org/10.1126/science.1154102.

Burke, L., Maidens, J., 2004. Reefs at Risk in the Caribbean. World Resources Institute, Washington, DC.

Burke, L., Katie Reytar, Mark Spalding, Perry, A.L., 2011. Reefs at Risk Revisited. World Resources Institute, Washington, DC.

Burke, L., Selig, E., Spalding, M., 2002. Reefs at Risk in Southeast Asia. World Resources Institute, Washington, DC.

Cinner, J.E., Fuentes, M.M.P.B., Randriamahazo, H., 2009. Exploring social resilience in madagascar's marine protected areas. Ecology and Society 14 (1), 41.

Cinner, J.E., McClanahan, T.R., 2006. Socioeconomic factors that lead to overfishing in small-scale reef fisheries in Papua New Guinea. Environmental Conservation 33, 73-80.

Cinner, J.E., McClanahan, T.R., Graham, N.A.J., Daw, T.M., Maina, J., Stead, S.M., Wamukota, A. Brown, K, Bodin, Ö. Vulnerability of coastal communities to key impacts of climate change on coral reef fisheries. Global Environmental Change (0). doi:10.1016/j.gloenvcha.2011.09.018. http:// www.sciencedirect.com/science/article/pii/ S0959378011001579.

Dey, M.M., Rab, M.A., Paraguas, F.J., Somying Piumsombun, Ramachandra Bhatta, Md Ferdous Alam, Mahfuzuddin Ahmed, 2005. Fish consumption and food security: a disaggregated analysis by types of fish and classes of consumers in selected Asian countries. Aquaculture Economics \& Management 9 (1-2), 89-111, http://dx.doi.org/ 10.1080/13657300590961537.

Dilley, M., Boudreau, T.E., 2001. Coming to terms with vulnerability: a critique of the food security definition. Food Policy 26 (June (3)), 229-247, http://dx.doi.org/10.1016/S03069192(00)00046-4.

Dulvy, N., Allison, E., 2009. “A Place at the Table?” (0906) (June): 68-70. doi:10.1038/climate.2009.52.

Ekbom, A., Bojö, J., 1997. Mainstreaming Environment in Country Assistance Strategies. Discussion Paper. World Bank, Washington, D.C.

FAO, 2011. The State of Food Insecurity in the World 2010. United Nations Food and Agriculture Organization, Rome.

Ghina, F., 2003. Sustainable development in small island developing states. Environment, Development and Sustainability 5 (1-2), 139-165.

Gregory, P.J., Ingram, J.S.I., Brklacich, M., 2005. Climate change and food security. Philosophical Transactions of the Royal Society B: Biological Sciences 360, 2139-2148.

Halpern, B.S., Walbridge, S., Selkoe, K.A., Kappel, C.V., Fiorenza Micheli, Caterina D'Agrosa, Bruno, J.F., et al., 2008. A global map of human impact on marine ecosystems. Science 319 (February (5865)), 948-952, http://dx.doi.org/10.1126/ science.1149345.

Hammond, J.S., Ralph Keeney, Howard Raiffa, 1999. Smart Choices: A Practical Guide to Making Better Decisions. Harvard University Press, Cambridge, MA.

Handmer, J.W., Dovers, S., Downing, T.E., 1999. Societal vulnerability to climate change and variability. Mitigation and Adaptation Strategies for Global Change 4, 267-281.

Hicks, C.C., McClanahan, T.R., Cinner, J.E., Hills, J.M., 2009. Trade-offs in values assigned to ecological goods and services associated with different coral reef management strategies. Ecology and Society 14 (1), 10.

Ionescu, C., Klein, R.J.T., Jochen Hinkel, Kavi Kumar, K.S., Rupert Klein, 2009. Towards a formal framework of vulnerability to climate change. Environmental Modeling and Assessment 14 (1), 1-16.

Jolliffe, I.T., 1986. Principal Component Analysis. SpringerVerlag, New York.

Kawarazuka, N., Bene, C., 2010. Linking small-scale fisheries and aquaculture to household nutritional security: an overview. Food Security 2 (4), 343-357.

Kawarazuka, N., Bene, C., 2011. The potential role of small fish species in improving micronutrient deficiencies in developing countries: building the evidence. Public Health Nutrition 14, 1927-1938.

Kent, G., 1997. Fisheries, food security, and the poor. Food Policy 22 (October (5)), 393-404, http://dx.doi.org/10.1016/S03069192(97)00030-4.

Langbein, L., Knack, S., 2010. The worldwide governance indicators: six, one, or none? Journal of Development Studies 46 (2), 350-370.

Leurs, A.L., 2005. The surface of vulnerability: an analytical framework for examining environmental change. Global Environmental Change 15, 214-223.

Luers, A.L., Lobell, D.B., Sklar, L.S., Addams, C.L., Matson, P.A., 2003. A method for quantifying vulnerability, applied to the agricultural system of the Yaqui Valley, Mexico. Global Environmental Change 13 (December (4)), 255-267, http:// dx.doi.org/10.1016/S0959-3780(03)00054-2.

McClanahan, T.R., 2002. The near future of coral reefs. Environmental Conservation 29, 460-483.

McClanahan, T.R., Cinner, J.E., Graham, N.A.J., Daw, T.M., Maina, J., Stead, S.M., Wamukota, A., Katrina Brown, Venus, V., Polunin, N.V.C., 2009. Identifying reefs of hope and hopeful actions: contextualizing environmental, ecological, 
and social parameters to respond effectively to climate change. Conservation Biology 23 (3), 662-671.

McClanahan, T.R., Cinner, J.E., Maina, J., Graham, N.A.J., Daw, T.M., Stead, S.M., Wamukota, A., et al., 2008. Conservation action in a changing climate. Conservation Letters 1 (2), 53-59, http://dx.doi.org/10.1111/j.1755-263X.2008.00008_1.x.

Mora, C., Myers, R.A., Coll, M., Libralato, S., Pitcher, T.J., 2009. Management effectiveness of the World's marine fisheries. PLoS Biology 7 (6), e1000131.

Newton, K., Cote, I.M., Pilling, G.M., Simon Jennings, Dulvy, N.K., 2007. Current and future sustainability of island coral reef fisheries. Current Biology 17 (7), 655-658.

Pandolfi, J.M., Connolly, S.R., Marshall, D.J., Cohen, A.L., 2011. Protecting coral reef futures under global warming and ocean acidification. Science 333, 418-422.

Pauly, D., Watson, R., Alder, J., 2005. Global Trends in World Fisheries: Impacts on Marine Ecosystems and Food Security. Philosophical Transactions of the Royal Society B: Biological Sciences 360 (January (1453)), 5-12, http://dx.doi.org/10.1098/ rstb.2004.1574.

Pelling, M., Uitto, J.I., 2001. Small island developing states: natural disaster vulnerability and global change. Environmental Hazards 3, 49-62.

Riley, J.C., 2005. Poverty and Life Expectancy. Cambridge University Press, Cambridge, UK.

Saaty, Thomas L., 1986. Decision Making for Leaders: The Analytic Hierarchy Process for Decisions in a Complex World. RWS Publications, Pittsburgh, PA.

Schmidhuber, J., Tubiello, F.N., 2007. Global food security under climate change. Proceedings of the National Academy of Sciences 104 (December (50)), 19703-19708, http://dx.doi.org/ 10.1073/pnas.0701976104.

Smit, B., Wandel, J., 2006. Adaptation, Adaptive Capacity and Vulnerability. Global Environmental Change 16 (August (3)), 282-292, http://dx.doi.org/10.1016/j.gloenvcha.2006.03.008.

Smith, M.D., Roheim, C.A., Crowder, L.B., Halpern, B.S., Turnipseed, M., Anderson, J.L., Asche, F., et al., 2010. Sustainability and global seafood. Science 327 (February (5967)), 784-786, http://dx.doi.org/10.1126/science.1185345.

Smith, S.V., Buddemeier, R.W., 1992. Global change and coral reef ecosystems. Annual Review of Ecology and Systematics 23 (1), 89-118.

Thorpe, A., Chris Reid, Raymon Van Anrooy, Cecile Brugere, 2005. Integrating Fisheries into the National Development Plans of Small Island Developing States (SIDS): ten years on from Barbados. Natural Resources Forum 29 (1), 51-69, http:// dx.doi.org/10.1111/j.1477-8947.2005.00112.x.

Thorpe, A., Chris Reid, Raymon van Anrooy, Cecile Brugere, Denis Becker, 2006. Asian development and poverty reduction strategies: integrating fisheries into the development discourse. Food Policy 31 (5), 385-400, http:// dx.doi.org/10.1016/j.foodpol.2005.09.007.

Turner, B.L., Kasperson, R.E., Matson, P.A., McCarthy, J.J., Corell, R.W., Lindsey Christensen, Noelle Eckley, et al., 2003. A framework for vulnerability analysis in sustainability science. Proceedings of the National Academy of Sciences 100 (14), 8074-8079.

Whittingham, E., Campbell, J., Townsley, P., 2003. Poverty and Reefs. DFID-IMM-IOC/UNESCO.

Wilkinson, C.R., Buddemeier, R.W., 1994. Global climate change and coral reefs: implications for people and reefs. Report of the UNEP-IOC-ASPEI-IUCN Global Task Team on the Implications of Climate Change on Coral Reefs. Gland, Switzerland: IUCN.

Sara Hughes is a postdoctoral fellow in the Research Applications Laboratory of the National Center for Atmospheric Research. Her research focuses on the role of social and political institutions in environmental policy and climate change adaptation. Sara received her PhD in 2011 in Environmental Science and Management from the University of California, Santa Barbara. Her previous work has examined the politics and institutions engaged in urban water management reform and currently Sara's research is aimed at better understanding the drivers of urban climate change planning and its implications for equity and development in the U.S., Asia, and Latin America.

Annie Yau earned a Ph.D. in Environmental Science and Management from the University of California, Santa Barbara in 2011. She developed methods to model and manage populations at small spatial scales under uncertainty in the amount of selfrecruitment, using the example of a giant clam fishery in French Polynesia. She currently advises on National Ocean Policy issues for the National Oceanic and Atmospheric Administration. Previously, she evaluated the sustainability of several fisheries for the Seafood Watch Program of the Monterey Bay Aquarium. She has also published on the photophysiology of symbiotic marine algae and best education practices for environmental education.

Lisa Max is a marine ecology $\mathrm{PhD}$ student in the Ecology, Evolution and Marine Biology Department at the University of California, Santa Barbara, and holds a Master's degree in Environmental Management from Yale University, School of Forestry and Environmental Studies. Lisa's dissertation focuses on food web dynamics in coral reef and kelp forest ecosystems.

Nada Petrovic is a Postdoctoral Fellow at the Center for Research on Environmental Decisions at Columbia University. She is broadly interested in how perceptions of environmental issues influence decisions on an individual and community level. In particular, she focuses on the interpretation and use of scientific information in the context of climate change and natural disasters. Her background is in physical science, and in her doctoral work she studied optimal decision-making for wildfire response using a numerical modeling approach.

Frank Davenport is a PhD student in Geography at UCSB. His research focuses on food security and spatial econometrics. Frank is interested in how trade liberalization impacts spatial price behavior among agricultural commodity markets. One of his dissertation papers analyzes how the response of Mexican maize prices to local and global influences varies over space and time during different stages of the North American Free Trade Agreement (NAFTA). Frank is also working with colleagues at the UCSB Climate Hazards Group to examine maize prices, climate trends, and child malnutrition in Kenya.

Michael Marshall is broadly interested in how coupled land surface-atmospheric processes impact agrarian society. He received his Ph.D. in Geography from UC Santa Barbara in 2010. His dissertation, titled Modeling Evapotranspiration in sub-Saharan Africa: A Tool for Food Security Analysis, synthesized remote sensing and land surface reanalysis to estimate evapotranspiration. He was recently awarded a Mendenhall Research Fellowship through the U.S. Geological Survey to combine ground, hyper- spatial and spectral remote sensing, and ancillary spatial data to estimate and evaluate crop water productivity.

Timothy R. McClanahan is a coral reef ecosystem ecologist with research interests spanning the fields of marine protected areas, food webs, nutrients, fisheries, climate change, resilience, and the linkages between coral reef ecosystems and the humans who depend on them. He has spent most of his professional life living and working in Kenya, and for the last 20 years has worked as a 
Senior Conservation Zoologist for the Wildlife Conservation Society, based in Mombasa, on the east African coast. His work has focused on providing solutions to human-coral reef fisheries interaction in poor developing countries.

Dr. Edward H. Allison has over 20 years' experience in the field of fisheries management and development in sub-Saharan Africa, Asia, Oceania, Latin America and the UK, as researcher or technical and policy advisor for various international organizations. He currently holds a part-time faculty position at the University of East Anglia, U.K, where his research focuses on the contribution of fisheries and aquaculture to food and nutrition security, and coastal and riparian people's vulnerability and adaptation to climate change. In 2013 he will take up a professorship in the
School of Marine and Environmental Affairs, University of Washington.

Dr. Joshua E. Cinner's research explores how social, economic, and cultural factors influence the ways in which people use, perceive, and govern natural resources, with a particular emphasis on using applied social science to inform coral reef management. His background is in human geography and he often works closely with ecologists to uncover complex linkages between social and ecological systems. He has worked on human dimensions of resource management in Jamaica, Mexico, Papua New Guinea, Kenya, Madagascar, Tanzania, Mauritius, Seychelles, Indonesia, Mozambique, and the USA. Dr. Cinner holds a prestigious Australian Research Fellowship from the Australian Research Council. 